\title{
Surfactant control of gas transfer velocity along an offshore coastal transect: results from a laboratory gas exchange tank
}

\author{
R. Pereira ${ }^{1,2}$, K. Schneider-Zapp ${ }^{2,3}$, and R. C. Upstill-Goddard ${ }^{2}$ \\ ${ }^{1}$ The Lyell Centre, Heriot-Watt University, Edinburgh, EH14 4AP, UK \\ ${ }^{2}$ School of Marine Science and Technology, Newcastle University, Newcastle upon Tyne, NE1 7RU, UK \\ ${ }^{3}$ Pix4D, EPFL Innovation Park, 1015 Lausanne, Switzerland \\ Correspondence to: R. Pereira (r.pereira@hw.ac.uk)
}

Received: 8 January 2016 - Published in Biogeosciences Discuss.: 18 January 2016

Revised: 14 April 2016 - Accepted: 7 June 2016 - Published: 11 July 2016

\begin{abstract}
Understanding the physical and biogeochemical controls of air-sea gas exchange is necessary for establishing biogeochemical models for predicting regional- and globalscale trace gas fluxes and feedbacks. To this end we report the results of experiments designed to constrain the effect of surfactants in the sea surface microlayer (SML) on the gas transfer velocity $\left(k_{\mathrm{w}} ; \mathrm{cm} \mathrm{h}^{-1}\right)$, seasonally (2012-2013) along a $20 \mathrm{~km}$ coastal transect (North East UK). We measured total surfactant activity (SA), chromophoric dissolved organic matter (CDOM) and chlorophyll $a(\mathrm{Chl} a)$ in the SML and in sub-surface water (SSW) and we evaluated corresponding $k_{\mathrm{w}}$ values using a custom-designed air-sea gas exchange tank. Temporal SA variability exceeded its spatial variability. Overall, SA varied 5-fold between all samples (0.08 to $\left.0.38 \mathrm{mg} \mathrm{L}^{-1} \mathrm{~T}-\mathrm{X}-100\right)$ ), being highest in the SML during summer. SML SA enrichment factors (EFs) relative to SSW were $\sim 1.0$ to 1.9 , except for two values $(0.75$; 0.89 : February 2013). The range in corresponding $k_{660}\left(k_{\mathrm{w}}\right.$ for $\mathrm{CO}_{2}$ in seawater at $20^{\circ} \mathrm{C}$ ) was 6.8 to $22.0 \mathrm{~cm} \mathrm{~h}^{-1}$. The film factor $R_{660}$ (the ratio of $k_{660}$ for seawater to $k_{660}$ for "clean", i.e. surfactant-free, laboratory water) was strongly correlated with SML SA $(r \geq 0.70, p \leq 0.002$, each $n=16)$. High SML SA typically corresponded to $k_{660}$ suppressions $\sim 14$ to $51 \%$ relative to clean laboratory water, highlighting strong spatiotemporal gradients in gas exchange due to varying surfactant in these coastal waters. Such variability should be taken account of when evaluating marine trace gas sources and sinks. Total CDOM absorbance (250 to $450 \mathrm{~nm}$ ), the CDOM spectral slope ratio $\left(S_{\mathrm{R}}=S_{275-295} / S_{350-400}\right)$, the $250: 365 \mathrm{~nm}$ CDOM absorption ratio $\left(E_{2}: E_{3}\right)$, and Chl $a$ all indicated spatial and temporal signals in the quantity and
\end{abstract}

composition of organic matter in the SML and SSW. This prompts us to hypothesise that spatiotemporal variation in $R_{660}$ and its relationship with SA is a consequence of compositional differences in the surfactant fraction of the SML DOM pool that warrants further investigation.

\section{Introduction}

The global budgets of important climate active gases such as carbon dioxide $\left(\mathrm{CO}_{2}\right)$, nitrous oxide $\left(\mathrm{N}_{2} \mathrm{O}\right)$ and methane $\left(\mathrm{CH}_{4}\right)$ have important marine components that are predicted to change in a future climate (Bakker et al., 2014). For $\mathrm{CO}_{2}$, uncertainty over the spatial and temporal variability of its water-side gas transfer velocity $\left(k_{\mathrm{w}}\right)$ is the greatest obstacle to accurately evaluating its net global rate of air-sea exchange (Takahashi et al., 2009, 2012). Environmental control of $k_{\mathrm{w}}$ is exerted through the modification of turbulent diffusion at the air-sea interface (Upstill-Goddard, 2006). Wind speed is the most fundamental control but its use for predicting $k_{\mathrm{w}}$ is compromised by high data scatter that is unrelated to methodological issues (Asher, 2009). The result is several parameterisations (e.g. Nightingale et al., 2000; Wanninkhof, 1992; Wanninkhof et al., 1997; Wanninkhof and McGillis, 1999) with differences that imply variable influences from other factors such as atmospheric stability, sea state, breaking waves, white caps, bubble transport, rain and the presence of surfactants and other organics (Upstill-Goddard, 2006).

The surface ocean boundary with the atmosphere is characterised by the sea surface microlayer (SML) which is $\sim 400 \mu \mathrm{m}$ or less deep and is physically and biogeochem- 
ically distinct from the underlying water (Cunliffe et al., 2013). Dissolved components and buoyant particles from the underlying water become enriched in the SML by bubble scavenging (Cunliffe at al., 2009, 2013; Gaŝparović et al., 1998; Petrović et al., 2002; Wurl et al., 2011; Źutić et al., 1981), leading to accelerated rates of microbiological and photochemical processes (Cunliffe et al., 2013; Vodacek et al., 1997; Häder et al., 2011). Material accumulating in the SML includes a range of surface active substances (surfactants) such as transparent exopolymer particles (TEP; Wurl and Holmes, 2008), polysaccharides (Sieburth et al., 1976), lipid-like material (Gaŝparović et al., 1998; Kattner and Brockmann, 1978; Lass and Friedrichs, 2011), amino acids (Kuznetsova et al., 2004) and chromophoric dissolved organic matter (CDOM; Tilstone et al., 2010). The tendency is for many of these components to be of lower molecular weight than their analogues in the underlying water (Lechtenfeld et al., 2013) and this may be coupled to in situ primary production (Chin et al., 1998; Passow 2002), allochthonous inputs of terrestrial material of either natural (e.g. Frew et al., 2006) or anthropogenic (Guitart et al., 2007) origin, and the photochemical and/or microbial reworking of higher molecular weight material (Tilstone et al., 2010; Schulz et al., 2013).

The SML is itself overlain by the surface nanolayer (SNL); this is $\sim 1$ to $10 \mathrm{~nm}$ thick and can be a monolayer, it also comprises of surface-active substances and it may be enriched in carbohydrates during summer (Lass et al., 2013). Its physicochemical properties differ from those of the SML, providing an additional diffusion barrier and modifying the viscoelasticity of the air-sea interface (McKenna and Bock, 2006). This reduces the rate of air-sea gas exchange by wave damping and by attenuating turbulent energy transfer (Liss and Duce, 1997). It is these effects that are manifested in reductions in the value of $k_{\mathrm{w}}$ (McKenna and McGillis, 2004; Salter et al., 2011).

While $k_{\mathrm{w}}$ suppression by surfactants ranging from 5 to $55 \%$ has been observed in the laboratory (Bock et al., 1999; Goldman et al., 1988) and at sea (Brockmann et al., 1982; Salter et al., 2011), this has mostly involved artificial compounds. The role of natural surfactants has remained inadequately quantified due to the complexity of measuring $k_{\mathrm{w}}$ in situ and the spatial and temporal variability in natural surfactant concentration and composition (Salter et al., 2011). Although Schmidt and Schneider (2011) examined the seasonal variability in $k_{\mathrm{w}}$ associated with changes in surfactant from measurements of $\mathrm{O}_{2}$ transfer and changes in surface tension, there remains a critical knowledge gap with respect to the spatiotemporal variability of $k_{\mathrm{w}}$ linked to surfactant. We therefore estimated the temporal variability in $k_{\mathrm{w}}$ along an offshore gradient in natural surfactant, using a laboratory gas exchange tank custom built for this purpose.

The overarching goal of this study was to derive a fundamental understanding of the spatial and temporal control of $k_{\mathrm{w}}$ variability by surfactant. Our testable hypothesis is that due to surfactant suppression of $k_{\mathrm{w}}$, inverse correlations be- tween $k_{\mathrm{W}}$ and surfactant activity (SA) in the SML should temporally persist in regions where SA shows high spatial variability. A secondary aim was to ascertain whether surfactant accumulation in the SML is strongly linked to primary productivity (using chlorophyll $a$ as a proxy) and whether CDOM could be used as a quantitative index of SA and $k_{\mathrm{w}}$, given its widespread use in remote sensing platforms.

\section{Materials and methods}

Sampling was at five, $5 \mathrm{~km}$ spaced stations along the Dove Time Series (DTS; Frid et al., 1999) transect off the North East UK coast, using RV Princess Royal. The purpose of the DTS is to monitor long-term changes in the plankton community structure of the North Sea (Clark, 2000). For this study we opportunistically sampled at established DTS sampling stations (Fig. 1). At each station the SML and underlying sub-surface water (SSW) were sampled in triplicate. To minimise contamination from R/V Princess Royal all samples were collected from near the bow whilst stationary and with the bow positioned upwind. Visual inspection for potential fouling from the research vessel prior to sampling aimed to ensure collection of a representative sample. Following a well-established protocol (Cunliffe et al., 2014), the SML was sampled using a Garrett screen (Garrett, 1965; mesh 16 , wire diameter $0.36 \mathrm{~mm}$, opening $1.25 \mathrm{~mm}$ ) with an effective surface area of $2025 \mathrm{~cm}^{2}$. At each station we made three Garrett screen dips, with a typical total yield for all three dips of 400 to $500 \mathrm{~mL}$, corresponding to an estimated sampling depth of 65 to $80 \mu \mathrm{m}$. The samples were transferred to three $50 \mathrm{~mL}$ high-density polyethylene (HDPE) bottles and stored in an on-board refrigerator at $4{ }^{\circ} \mathrm{C}$ (Cunliffe et al., 2013; Schneider-Zapp et al., 2013). SSW ( 100 L) was sampled from a non-toxic supply pump located $\sim 1 \mathrm{~m}$ below the water surface and collected in $5 \times 20 \mathrm{~L}$ HDPE carboys that were pre-cleaned with $20 \% \mathrm{HCl}$ to remove leachable organics. SSW temperature and salinity were measured in situ (Hanna Instruments, UK). In the absence of directly measured wind speed, monthly mean wind speeds of daily means at $10 \mathrm{~m}\left(U_{10}\right)$ from January 2012 to December 2013 were obtained from the ERA Interim reanalysis data set supplied by the European Centre for Medium-Range Weather Forecasts (http://www.ecmwf.int/). During our study period $U_{10}$ ranged from 4.7 to $11.4 \mathrm{~m} \mathrm{~s}^{-1}$ with the highest values between October and February and lowest values in June and July. On return to the laboratory, typically within $6 \mathrm{~h}$ of sampling, all samples were stored in a $4^{\circ} \mathrm{C}$ dark cold room according to the procedure of Schneider-Zapp et al. (2013). The SML and SSW were analysed for surfactant activity (SA) and chromophoric dissolved organic matter (CDOM) absorbance and the SSW was additionally analysed for Chlorophyll $a$ $(\mathrm{Chl} a$ ). All analyses were completed within $12 \mathrm{~h}$.

Surfactant activity (SA) was measured in triplicate by phase-sensitive AC voltammetry (797 VA Computrace: 


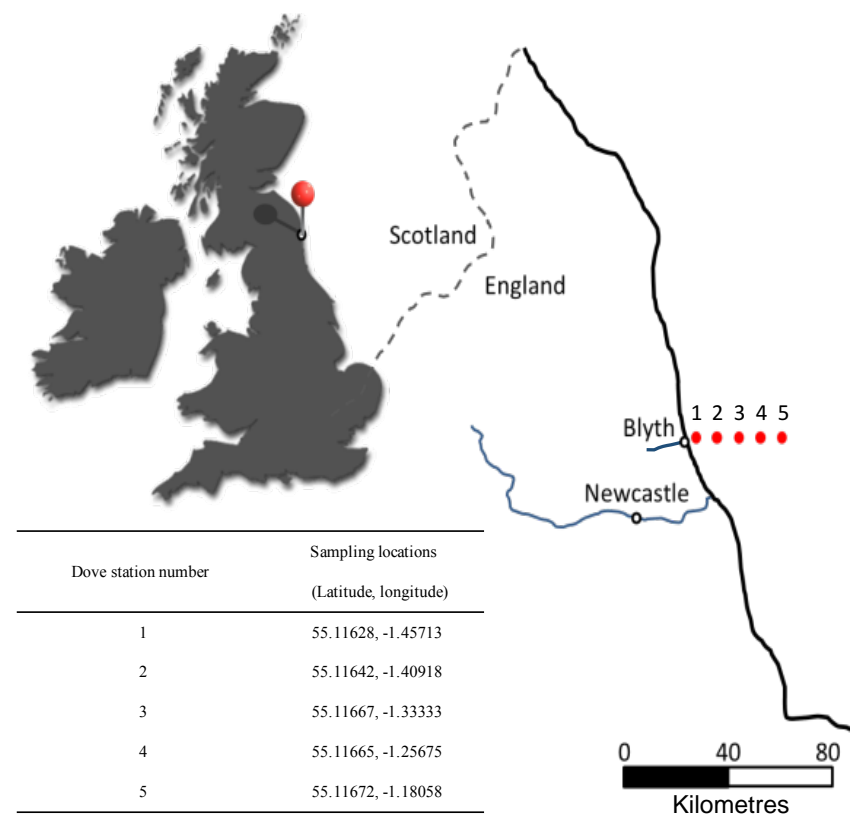

Figure 1. Location map of the Dove Time Series sampling transect 2012-2013 off the coast of Blyth, North East England.

Metrohm, Switzerland) using a hanging mercury drop (Ćosović and Vojvodić, 1982) with sample salinities pre-adjusted to 35.0 via the addition of surfactant-free $3 \mathrm{~mol} \mathrm{~L}^{-1} \mathrm{NaCl}$ solution. Calibration was against the non-ionic soluble surfactant Triton T-X-100. All equipment was acid-washed (10\% $\mathrm{HCl})$ and analytical grade water-rinsed (18.2 Ohm Milli-Q, Millipore System Inc., USA) prior to use.

Chl $a$ was determined fluorometrically (Welschmeyer, 1994). In brief, $0.5 \mathrm{~L}$ of each seawater sample was filtered through a $0.2 \mu \mathrm{m}, 47 \mathrm{~mm}$ diameter Nylon membrane filter (Knefelkamp et al., 2007). The filters were subsequently extracted in acetone and the extract analysed using a Turner Designs Trilogy fluorometer (USA) calibrated with a known pure Chl $a$ standard (Anacystis nidulans, Sigma Aldrich).

CDOM absorbance (wavelength range 800 to $250 \mathrm{~nm}$ ) was determined on unfiltered seawater in $1 \mathrm{~nm}$ steps by UV-Vis spectrophotometry (Varian Cary 100 Bio; Varian Inc, USA), using $10 \mathrm{~cm}$ path length quartz cuvettes pre-rinsed three times with ultra-pure water (Milli-Q: Millipore System Inc., USA). Spectra were blank corrected using Milli-Q water and for machine drift using the mean absorption from $700 \mathrm{~nm}$ to $800 \mathrm{~nm}$. Measurements were made in triplicate and Naperian absorbance coefficients $a\left(\mathrm{~m}^{-1}\right)$ were determined following $\mathrm{Hu}$ et al. (2002). For each measurement the mean value and standard error of the mean is reported.

We chose not filter our CDOM samples based on our earlier work (Kitidis et al., 2006; Stubbins et al., 2006) that established strong relationships between CDOM in filtered and unfiltered seawater for coastal and oceanic waters. Filtration can lead to the contamination of dissolved organic carbon (DOC) and UV absorbance (Ferrari, 2000; Karanfil et al., 2003; Kitidis et al., 2006). Although our samples include both dissolved and particulate components of absorbance and are subject to scattering by particles that include living phytoplankton (Nelson and Siegel, 2013 and references therein), any potential effects on our CDOM measurements can be considered minor relative to those likely to be introduced during filtration. Total CDOM absorbance was calculated as the integrated absorbance from 250 to $450 \mathrm{~nm}$ at a 1-nm resolution (Helms et al., 2008). The $250: 365 \mathrm{~nm}$ absorption ratio $\left(E_{2}: E_{3}\right)$ was used to track relative changes in low molecular weight (LMW) vs. high molecular weight (HMW) organic matter $(\mathrm{OM}) ; E_{2}: E_{3}$ decreases with increasing OM molecular size due to increasing light absorption by HMW OM towards longer wavelengths (Peuravuori and Pihlaja, 1997). Spectral slope $(S)$ was calculated using a nonlinear fit of an exponential function to the absorption spectrum over the ranges 275 to 295 and 350 to $400 \mathrm{~nm}$ (Helms et al., 2008). The spectral slope ratio, $S_{\mathrm{R}}\left(=S_{275-295} / S_{350-400}\right)$, was used to broadly characterize $\mathrm{OM}$ in terms of molecular weight and source; samples with low $S_{\mathrm{R}}$ are of high molecular weight and have a greater tendency to be allochthonous (Helms et al., 2008). Due to instrument maintenance no CDOM measurements are available for the 17 September 2013 survey.

The SSW samples (volume $\sim 93 \mathrm{~L}$ ) were used to estimate the spatial variability in $k_{\mathrm{w}}$ using a fully automated, closed air-water gas exchange tank. Tank design, operation and routine procedures for its rigorous cleaning are all described in detail in Schneider-Zapp et al. (2014). In brief, the system generates water-side turbulence with an electronic baffle operated at three increasingly turbulent boundary conditions of $0.6,0.7$, and $0.75 \mathrm{~Hz}$. Although turbulence created in a laboratory tank inevitably differs from turbulence in situ, which is primarily wind-driven, our experimental system avoids the practical complications of simulating wind-induced turbulence in a laboratory while maintaining well-defined and reproducible conditions (Schneider-Zapp et al., 2014). The purpose of the tank is to facilitate an improved understanding of $k_{\mathrm{w}}$ suppression by natural surfactants that will subsequently enable more complex experiments involving winddriven turbulence. We used SSW in the tank experiments for two reasons. First, there is no practical procedure for collecting a large volume sample of surface seawater that preserves the integrity of the SML. Second, we have shown (i) that following its disturbance by vigorous mixing in a laboratory tank the SML becomes re-established on a time scale of seconds with respect to surfactants and other SML components (Cunliffe et al., 2013); (ii) that a new SML is similarly established when sub-surface coastal waters are pumped into large mesocosm tanks (Cunliffe et al., 2009).

The tank is coupled to two gas chromatographs (GCs) and an integral equilibrator in a continuous gas-tight loop (Schneider-Zapp et al., 2014). This enables temporal changes in the partial pressures of gaseous tracers artificially enriched in the tank water $\left(\mathrm{SF}_{6}, \mathrm{CH}_{4}\right.$, and $\left.\mathrm{N}_{2} \mathrm{O}\right)$ to be measured si- 
multaneously in tank water and headspace, thereby deriving three independent estimates of $k_{\mathrm{w}}$ for each turbulence setting. Due to the dependence of $k_{\mathrm{w}}$ on the Schmidt Number ( $S c$ : the ratio of kinematic viscosity to gas diffusivity) raised to the power $n$ (Upstill-Goddard, 2006), the $k_{\mathrm{W}}$ estimates were converted to $k_{660}$, the value of $k_{\mathrm{w}}$ for $S c=660$ (the value for $\mathrm{CO}_{2}$ in seawater at $20^{\circ} \mathrm{C}$ ), assuming $n=0.5$ for a wavy surface (Upstill-Goddard, 2006). As the work presented here pre-dates the installation of an analytical capability for $\mathrm{N}_{2} \mathrm{O}$ reported in Schneider-Zapp et al. (2014), our $k_{660}$ estimates are based on $\mathrm{CH}_{4}$ and $\mathrm{SF}_{6}$ only. To check for any biogenic changes to tracer concentrations, their loss via leakage or problems arising from GC analytical drift, the total masses of $\mathrm{CH}_{4}$ and $\mathrm{SF}_{6}$ were continually estimated over the duration of the experiments, from their measured partial pressures and the known water and air volumes (mass balance; SchneiderZapp et al., 2014, Eq. 14). Experiments with a significant mass balance error $(> \pm 5 \%$ mass drift throughout the entire experiment) were excluded. For this study most of our $\mathrm{SF}_{6}$ data failed the mass balance test because they fell outside the linear range of the GC detector. Consequently, we have excluded any analyses deriving from our $\mathrm{SF}_{6} k_{\mathrm{W}}$ data, even though the resulting values of $k_{660}$ agree well with those obtained with $\mathrm{CH}_{4}$.

The uncertainty in each $k_{660}$ measurement was derived via Gaussian error propagation (Schneider-Zapp et al., 2014; Tayler, 1996) and is typically smaller than $\pm 0.8 \mathrm{~cm} \mathrm{~h}^{-1}(n=$ $48)$. We ascribe one result outside this range $\left( \pm 3.9 \mathrm{~cm} \mathrm{~h}^{-1}\right)$ to salt crystal formation that we observed in the water equilibration circuit. To clarify the comparative SA effect on $k_{\mathrm{w}}$ between sites we normalised our derived $k_{660}$ values to the value of $k_{660}$ derived in identical experiments in which the seawater samples were replaced by surfactant-free Milli-Q water (i.e. $R_{660}=k_{660}$ Sample $/ k_{660}$ Milli-Q) (Schneider-Zapp et al., 2014).

\section{Results and discussion}

Figure 2 shows the spatial and temporal variability of SA, total CDOM absorbance from 250 to $450 \mathrm{~nm}\left(\mathrm{CDOM}_{250-450}\right)$, $E_{2}: E_{3}$ and $S_{\mathrm{R}}$. For all four parameters temporal variability generally exceeded spatial variability, both in the SML and in SSW (Supplement Tables S1 and S2). In both SA was highest during June-July (SML; 0.25 to $0.38 \mathrm{mg} \mathrm{L}^{-1} \mathrm{~T}$-X$100, n=8$, SSW; 0.09 to $\left.0.28 \mathrm{mg} \mathrm{L}^{-1} \mathrm{~T}-\mathrm{X}-100, n=8\right)$ and lowest during October-February (SML; 0.08 to $0.27 \mathrm{mg} \mathrm{L}^{-1}$ T-X-100, $n=10$, SSW; 0.09 to $\left.0.19 \mathrm{mg} \mathrm{L}^{-1}, n=10\right)$. SA was generally higher in the SML than in SSW, as previously observed (e.g. Wurl et al., 2011), and our values for both the SML and SSW are broadly consistent with those from an earlier study in this region of the coastal North Sea (Salter, 2010), although that work also reported an exceptionally high SA value $\left(1.42 \mathrm{mg} \mathrm{L}^{-1} \mathrm{~T}-\mathrm{X}-100\right)$ coincident with a period of extreme river discharge that we did not experi- ence. Our SA data also agree well with those obtained under non-slick conditions in the Santa Barbara Channel, California (Wurl et al., 2009), but they are at the low end of the range presented by Wurl et al. (2011) for the open ocean.

$\mathrm{SA}$ enrichment factors $\left(\mathrm{EF}=\mathrm{C}_{\mathrm{SML}} / C_{S S W}\right.$; $C=$ concentration) ranged between $\sim 1.0$ and 1.9 , except for 2 samples collected in February 2013 for which SA was more enriched in SSW $(\mathrm{EFs}=0.75$ and 0.89 , respectively). While in SSW there was an overall decrease in SA with increasing distance offshore, SA in the SML was more spatially and temporally variable (Fig. 2). Although two surveys (4 October 2012; 10 June 2013) clearly show an overall decrease in SA offshore the evidence is inconclusive because the remaining two transects shows either no clear overall trend (13 February 2013) or are incomplete (17 July 2013). These EFs are broadly consistent with values for the global ocean (Wurl et al., 2011) despite our SA values being lower overall. Importantly, there is a clear relationship between SA in the SML and SA in the SSW $\left(r^{2}=0.81\right.$, $\left.p=<0.001, \quad n=18, \quad \mathrm{SA}_{\mathrm{SSW}}=0.7664 \mathrm{SA}_{\mathrm{SML}}+0.0183\right)$. This is supportive of the notion that SA in the SML is constantly renewed from the SSW (Cunliffe et al., 2013).

Total $\mathrm{CDOM}_{250-450}$ ranged from 240 to 874 in the SML and 217 to 792 in the SSW $(n=15)$, ranges that are consistent with those for high salinity waters in the Chesapeake Bay (Helms et al., 2008). $\mathrm{CDOM}_{250-450}$ decreased offshore by up to a factor $\sim 4$ (166 to 875 ) in both the SML and SSW. However, $\mathrm{CDOM}_{250-450}$ was generally higher in the SML than in SSW (EFs $=0.8$ to 1.8), similar to the case for SA. This is indicative of an accumulation of light absorbing components in the SML. Using the $E_{2}: E_{3}$ and $S_{\mathrm{R}}$ indices as tracers for OM composition we found that $E_{2}: E_{3}$ was generally lower in the SML (2.46 to 6.83, $n=15$ ) than in SSW ( 2.25 to $8.43, n=15 ; \mathrm{EFs}=0.7$ to 1.1 ), similar to $S_{\mathrm{R}}$ (SML; 1.11 to $1.99, n=15$, SSW; 1.37 to $2.25, n=15 ; \mathrm{EFs}=0.6$ to 1.2). These ranges for both $E_{2}: E_{3}$ and $S_{\mathrm{R}}$ are consistent with values reported for the Chesapeake Bay (Helms et al., 2008). In our study $E_{2}: E_{3}$ showed an opposite tendency to $\mathrm{CDOM}_{250-450}$, progressively increasing seaward by up to a factor $\sim 4$ (2.3 to 8.43). In contrast, $S_{\mathrm{R}}$ was generally higher in the SSW than in the SML and it exhibited both increases and decreases with distance offshore. Unlike SA, this latter behaviour characterised both the SML and SSW (Fig. 2). In October $2012 S_{\mathrm{R}}$ generally increased with distance offshore but in February and June 2013 it generally decreased offshore.

In earlier work $E_{2}: E_{3}$ was considered largely independent of total CDOM absorbance (Helms et al., 2008); however, whilst we observed a weaker and less significant relationship between $\mathrm{CDOM}_{250-450}$ and $E_{2}: E_{3}$ in the SML $\left(r^{2}=0.45, p=0.06, n=15\right)$, we found a strong relationship in SSW $\left(r^{2}=0.69, \mathrm{p}=<0.001, n=15\right)$. In contrast, we found no consistent relationship for either $\mathrm{CDOM}_{250-450}$ or $E_{2}: E_{3}$ with $\mathrm{S}_{\mathrm{R}}$. We tentatively propose that the divergence we specifically observed between $E_{2}: E_{3}$ and $S_{\mathrm{R}}$ in 

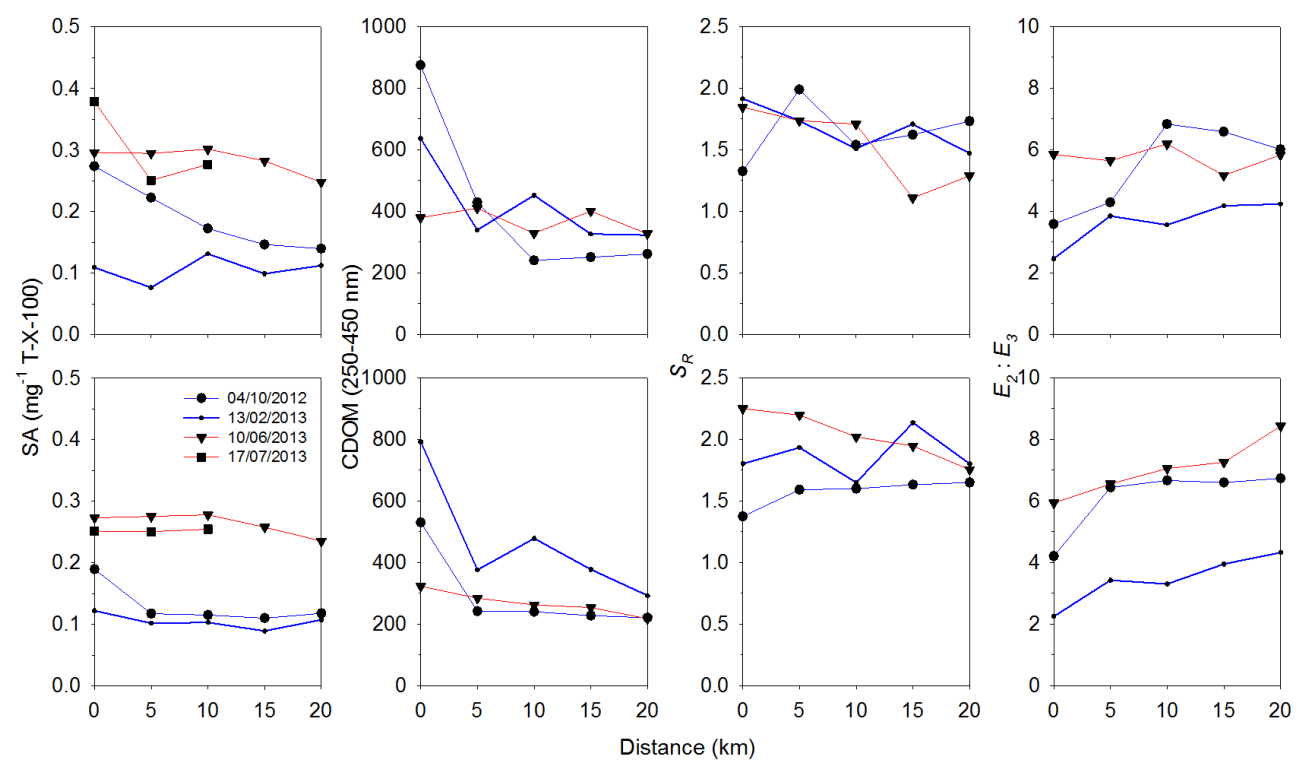

Figure 2. Surfactant activity (normalised to Triton T-X-100), CDOM (Total $a 250$ to $450 \mathrm{~nm}$ ), $S_{\mathrm{R}}$ and $E_{2}: E_{3}$ ratio of the sea surface microlayer (SML; top panels) and sub-surface water (SSW; bottom panels) from North Sea transects during $2012-2013$.

February and June 2013 may be related to additional higher molecular weight organic matter of autochthonous origin during this period. However, there is no apparent relationship between Chl $a$ in the SSW (range 0.09 to $1.54 \mathrm{mg} \mathrm{L}^{-1}$, $n=20$; Table S2), which is a proxy for in situ primary productivity (e.g. Frka et al., 2011), and either $\mathrm{CDOM}_{250-450}$, $E_{2}: E_{3}$ or $S_{\mathrm{R}}$. Unequivocally establishing the underlying reasons for this requires additional surveys coupled with more advanced molecular characterisation of OM (e.g. Lechtenfeld et al., 2013) and consideration of the potential roles of other light absorbing compounds (see review by Nelson and Siegel, 2013).

We similarly interpret the observed temporal variability in SA as a consequence of the mixing of SA sources related to at least two distinct marine and terrestrial endmembers. Likely candidates are terrestrially derived SA from the nearby River Blyth and autochthonous SA from in situ biological activity. The relatively high SA and $\mathrm{CDOM}_{250-450}$ at site $1(0 \mathrm{~km}$, directly at the mouth of the river), which is a persistent feature of the data, is consistent with this explanation if it is assumed that the terrestrial SA endmember source is more abundant there than autochthonous derived SA. This scenario is supported by the lack of any clear relationship between SA and $\mathrm{Chl} a$. Furthermore, despite the covariance between $E_{2}: E_{3}$ and $\mathrm{CDOM}_{250-350}$, the overall decrease in $\mathrm{CDOM}_{250-450}$ and increase $E_{2}: E_{3}$ with distance offshore implies either dilution of terrestrially derived CDOM with lower molecular weight marine CDOM or photochemical degradation of higher molecular weight material. This is in agreement with other studies that showed either HMW CDOM breakdown by photochemical or microbial processes (e.g. Helms et al., 2008, 2013) or an in situ supply of LMW CDOM to the most seaward sites via primary productivity (i.e. lipid production; Frka et al., 2011). Either of these processes could explain the observed relationship between $E_{2}: E_{3}$ and $\mathrm{CDOM}_{250-450}$ but further work clarifying the dominant pathways of $\mathrm{OM}$ processing in our study area is required. As for total SA, these data reveal a distinction between the SML and SSW as previously observed (Frew et al., 2006; Wurl et al., 2009, 2013; Lechtenfeld et al., 2013; Cunliffe et al., 2013; Engel and Galgani 2016). The generally higher SSW values of $S_{\mathrm{R}}$ and $E_{2}: E_{3}$ noted earlier suggest that SML DOM is predominantly of HMW, as compared to predominantly LMW DOM in SSW. Although River Blyth discharge data (National River Flow Archive Centre for Ecology and Hydrology; http://www.ceh.ac.uk/data/nrfa/) show no clear relationship between river flow and either SA or CDOM at site 1, our observations of SA and $\mathrm{CDOM}_{250-450}$ are broadly consistent with the results of a study in Cape Cod coastal waters (Frew et al., 2004), although in that study the offshore gradients in SA were much stronger than those we found off the NE UK coast. We also note that the River Blyth is rather small (mean annual discharge $\sim 2 \mathrm{~m}^{3} \mathrm{~s}^{-1}$ ) and this is reflected in the very weak salinity gradients that we observed (range typically \pm 0.6 ).

The values we derived for $k_{660}$ using our gas exchange tank (Table S3: 6.82 to $22.06 \mathrm{~cm} \mathrm{~h}^{-1}$ ) are realistic in that they are within the reported natural $k_{660}$ range of 5.81 to $70.17 \mathrm{~cm} \mathrm{~h}^{-1}$ (Asher, 2009). Even so, it was not our intention to reproduce conditions leading to the generation of turbulence in situ, which is in any case unachievable in a laboratory setting due to the multiple and variable controls of both water- and air-side turbulence (Upstill-Goddard, 2006). It is also important to reiterate that our approach was specifically 
designed to produce comparative $k_{660}$ estimates at controllable and reproducible turbulence levels and that as such, the mode of turbulence generation (water-side: motor driven baf$\mathrm{fle}$ ) is of secondary importance. Generally we found increasing $k_{660}$ with increasing water-side turbulence (Table S3). Even so, at the highest turbulence setting the data were comparatively noisy.

We found a strong correlation between $R_{660}$ in our tank experiments and SA in the SML in situ (Fig. 3). Along with our observation of strong correlations between SA in the SML and in the SSW, this finding reinforces the notion of continual SML renewal from the underlying water (Hardy et al., 1982; Frew, 2006; Cunliffe et al., 2013). The strongest linear relationships between $R_{660}$ and SA in situ in the SML were observed at $0.6 \mathrm{~Hz}\left(r^{2}=0.61, p=<0.001, n=16\right)$ and $0.7 \mathrm{~Hz}$ $\left(r^{2}=0.70, p=<0.001, n=16\right)$. At $0.75 \mathrm{~Hz}$ the relationship was notably weaker $\left(r^{2}=0.49, p=0.02, n=16\right)$ and only if a non-linear fit is applied to the data does the correlation coefficient improve. Although this could imply a threshold level of turbulence beyond which the surfactant effect on $k_{660}$ is rapidly attenuated in situ, we think it more likely indicates the limitations of the method at high baffle speeds due to the formation of bubbles and/or wave breaking and aerosol generation. We observed a similar phenomenon with an earlier gas exchange tank design (Upstill-Goddard et al., 2003). Further data are required to distinguish between these possibilities and to more robustly establish the relationships between $\mathrm{SA}$ and $R_{660}$. We found no significant relationships between $R_{660}$ and either Chl $a, \mathrm{CDOM}_{250-450}, S_{\mathrm{R}}, E_{2}: E_{3}$ or other specific CDOM wavelengths (e.g. $\lambda_{254}, \lambda_{300}, \lambda_{330}, \lambda_{350}$ or $\left.\lambda_{443}\right)$ in situ, in either the SML or SSW.Given this evidence, the use of remotely sensed CDOM as predictor of $k_{\mathrm{w}}$ variability over large spatial scales may well prove erroneous.

Our derived $R_{660}$ values (Fig. 3 and Table S3) correspond to $k_{660}$ suppressions of 14 to $51 \%$ for our samples (Fig. 3; $R_{660}=0.86$ to $0.49, n=48$ ) and highlight the effect of $k_{\mathrm{w}}$ suppression by natural surfactants in seawater as compared to surfactant-free water. We generally observed $k_{\mathrm{W}}$ suppression to be higher (i.e., lowest $\left.R_{660}\right)$ at near-shore sites $(<5 \mathrm{~km})$ than at off-shore sites $(>5 \mathrm{~km})$. This is most clearly shown for $k_{660}$ derived for the lowest turbulence setting $(0.6 \mathrm{~Hz})$ in June 2013 , for which $R_{660}$ at the most near-shore site was $\sim 10 \%$ lower than at the most offshore site. We also observed the largest seasonal variance in $R_{660}$ at the most near-shore site; the range in $k_{\mathrm{W}}$ suppression was 15 to $24 \%$ (Fig. 3 ). Site 3 located $10 \mathrm{~km}$ offshore showed the highest variance in $R_{660}$ at the highest baffle setting but was consistently observed to show a high variability in $R_{660}$ between summer (June/July) and autumn/winter (October/February) regardless of changes in turbulence. The range of $k_{\mathrm{w}}$ suppressions we observed (15 to $24 \%$ ) is within the range of previous laboratory work that demonstrated 10 to $90 \%$ surfactant suppression of $\mathrm{O}_{2}$ exchange for oceanic and coastal waters (Frew, 1997; Goldman et al., 1988) and $k_{\mathrm{w}}$ reductions of 5 to $50 \%$ for phytoplankton exudates (Frew et al., 1990). Similarly, laboratory and
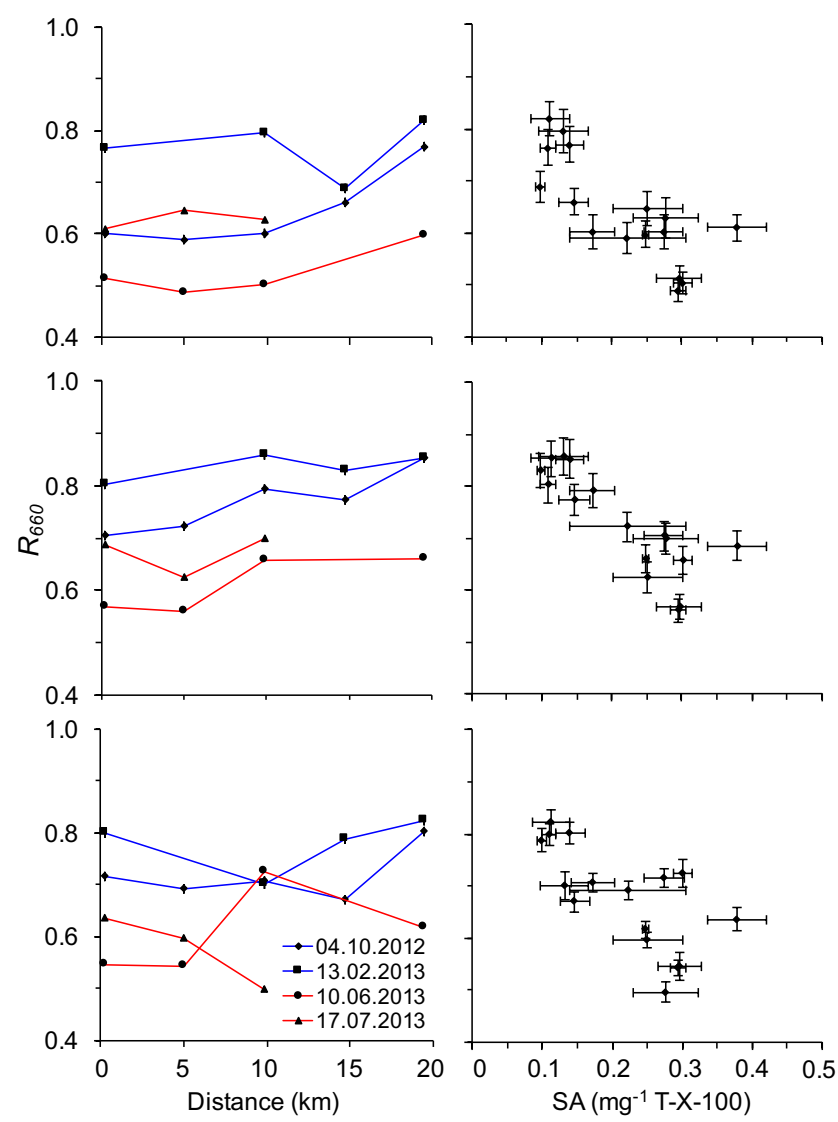

Figure 3. Left panels are $R_{660}$ for $\mathrm{CH}_{4}$ in seawater samples collected along the Dove Time Series transect in the North Sea during 2012-2013. Right panels are scatter plots of the $R_{660}\left(R_{660}=\right.$ $k_{660}$ Sample $/ k_{660}$ Milli-Q) and surfactant activity (SA) in the SML. The top two windows are for a tank baffle frequency of $0.6 \mathrm{~Hz}$, the two middle windows are for a tank baffle frequency $0.7 \mathrm{~Hz}$ and bottom two windows are for a tank baffle frequency of $0.75 \mathrm{~Hz}$.

field experiments with artificial surfactants found 60 to $74 \%$ $k_{\mathrm{W}}$ suppression (Brockmann et al., 1982; Bock et al., 1999; Frew, 1997; Salter et al., 2011).

Given that our methodological approach was specifically designed to constrain the effect of surfactants in the SML on $k_{\mathrm{W}}$ and that this minimised the effects of other potential $k_{\mathrm{W}}$ controls, our observations of distinct changes in the quantity and composition of OM in the SML and SSW prompt us to hypothesise that the observed spatiotemporal variation in $R_{660}$ and its relationship with SA (Fig. 3) is a consequence of compositional differences in the surfactant fraction of the SML DOM pool. The principal driver of this hypothesis is the data scatter inherent in the relationship between $R_{660}$ and $\mathrm{SA}$. While we have not been able to unequivocally relate any control of $k_{\mathrm{W}}$ to CDOM absorbance characteristics, and by inference CDOM composition, we nevertheless hypothesise that a rigorous characterisation of the chemical composition of the surfactant pool will yield important insights into sur- 
factant sources and biogeochemical processing that, when analysed in the context of physical forcing such as variable wind regime and hydrography (e.g. Chen et al., 2013; Frew et al., 2006; Gaŝparović et al., 2007; Lechtenfeld et al., 2013), will inform a better understanding of the spatial and temporal variability in $k_{\mathrm{w}}$.

\section{Implications}

Understanding the physical and biogeochemical controls of air-sea gas exchange is necessary for establishing biogeochemical models for predicting regional- and global-scale trace gas fluxes and feedbacks. Our results demonstrate the potential of our gas exchange tank concept in providing important information of this nature. In estimating ocean $\mathrm{CO}_{2}$ uptake for example, the spatiotemporal variability of $k_{\mathrm{W}}$ is now a much larger uncertainty than the spatiotemporal variability of $p \mathrm{CO}_{2}$ (Takahashi et al., 2009). For $\mathrm{CO}_{2}$ and other climate-active gases that have strong sources and sinks in coastal waters (e.g. $\mathrm{CH}_{4}, \mathrm{~N}_{2} \mathrm{O}$, halocarbons) it is equally important to quantify the degree of spatiotemporal variability in $k_{\mathrm{W}}$ so as to better constrain regional trace gas budgets (Prowe et al., 2009; Thomas et al., 2004, 2007; Tsunogai et al., 1999). Clearly, this must involve resolving the influence on $k_{\mathrm{W}}$ exerted not only by changes in total surfactant amount in the SML but also by variability in the composition of the surfactant pool and in the composition of the overall DOM pool. We anticipate that further seasonal measurements of the type described in this paper, both at coastal and ocean basin scales, will move us some way towards an eventual full parameterisation of the environmental controls of $k_{\mathrm{w}}$, and in particular the evidently important roles played by spatial and temporal trends in both surfactant amount and composition.

\section{The Supplement related to this article is available online at doi:10.5194/bg-13-3981-2016-supplement.}

Acknowledgements. This research was facilitated by grants from the Leverhulme Trust (RPG-303) and the UK Natural Environment Research Council (NE/IO15299/1) to RCU-G and from the German Research Foundation (DFG research fellowship) to KS-Z. We also thank the crew of R/V Princess Royal for field and logistical support, and Juliane Bischoff, Jon Barnes and David Whitaker for their technical advice and analytical assistance.

Edited by: G. Herndl

\section{References}

Asher, W. E.: The effects of experimental uncertainty in parameterizing air-sea gas exchange using tracer experiment data, Atmos. Chem. Phys., 9, 131-139, doi:10.5194/acp-9-131-2009, 2009.

Bakker, D. E., Bange, H., Gruber, N., Johannessen, T., UpstillGoddard, R., Borges, A., Delille, B., Löscher, C., Naqvi, S. W., Omar, A., and Santana-Casiano, J. M.: Air-Sea Interactions of Natural Long-Lived Greenhouse Gases $\left(\mathrm{CO}_{2}, \mathrm{~N}_{2} \mathrm{O}, \mathrm{CH}_{4}\right)$ in a Changing Climate, in: Ocean-Atmosphere Interactions of Gases and Particles, edited by: Liss, P. S. and Johnson, M. T., Springer Earth System Sciences, Springer Berlin Heidelberg, 113-169, 2014.

Bock, E. J., Hara, T., Frew, N. M., and McGillis, W. R.: Relationship between air-sea gas transfer and short wind waves, J. Geophys. Res.-Ocean., 104, 25821-25831, 1999.

Brockmann, U. H., Huhnerfuss, H., Kattner, G., Broecker, H. C., and Hentzschel, G.: Artificial surface-films in the sea area near Sylt, Limnol. Oceanogr., 27, 1050-1058, 1982.

Chen, Y., Yang, G. P., Wu, G. W., Gao, X. C., and Xia, Q. Y.: Concentration and characterization of dissolved organic matter in the surface microlayer and subsurface water of the Bohai Sea, China, Cont. Shelf Res., 52, 97-107, 2013.

Chin, W. C., Orellana, M. V., and Verdugo, P.: Spontaneous assembly of marine dissolved organic matter into polymer gels, Nature, 391, 568-572, 1998.

Clark, R.: University of Newcastle upon Tyne, Department of Marine Sciences Coastal Management, Long Term Changes in the North Sea Ecosystem, PhD Thesis, 2000.

Ćosović, B. and Vojvodić, V.: The Application of ac Polarography to the Determination of Surface-Active Substances in Sea-Water, Limnol. Oceanogr., 27, 361-368, 1982.

Cunliffe, M., Harrison, E., Salter, M., Schaefer, H., UpstillGoddard, R. C., and Murrell, J. C.: Comparison and validation of sampling strategies for the molecular microbial analysis of surface microlayers, Aquat. Microb. Ecol., 57, 69-77, 2009.

Cunliffe, M.: Physiological and Metabolic Effects of Carbon Monoxide Oxidation in the Model Marine Bacterioplankton Ruegeria pomeroyi DSS-3, Appl. Environ. Microbiol., 79, 738740, 2013.

Cunliffe, M., Wurl, O., Engel, A., Frka, S., Landing, W., Latif, M. T., Yang, G.-P., Zappa, C., Upstill-Goddard, R., Gaŝparović, B., Lindroos, A., Leal, M., Vagle, S., Ekau, W., Stolle, C., Soloviev, A., and Lass, K.: Guide to best practices to study the ocean's surface, Marine Biological Association of the United Kingdom, 118, 19-28, 2014.

Engel, A. and Galgani, L.: The organic sea-surface microlayer in the upwelling region off the coast of Peru and potential implications for air-sea exchange processes, Biogeosciences, 13, 989-1007, doi:10.5194/bg-13-989-2016, 2016.

Ferrari, G. M.: The relationship between chromophoric dissolved organic matter and dissolved organic carbon in the European Atlantic coastal area and in the West Mediterranean Sea (Gulf of Lions), Mar. Chem., 70, 339-357, 2000.

Frew, N.: The sea surface and global change, Cambridge University Press, Cambridge, New York, 1997.

Frew, N., Nelson, R., and Johnson, C.: Sea slicks: variability in chemical composition and surface elasticity, in: Marine Surface Films, edited by: Gade, M., Hühnerfuss, H., and Korenowski, G., Springer Berlin Heidelberg, 45-56, 2006. 
Frew, N. M., Goldman, J. C., Dennett, M. R., and Johnson, A. S.: Impact of phytoplankton-generated surfactants on air-sea gasexchange, J. Geophys. Res.-Ocean., 95, 3337-3352, 1990.

Frid, C. L. J., Clark, R. A., and Hall, J. A.: Long-term changes in the benthos on a heavily fished ground off the NE coast of England, Mar. Ecol. Prog. Ser., 188, 13-20, 1999.

Frka, S., Gašparović, B., Marić, D., Godrijan, J., Djakovac, T., Vojvodić, V., Dautović, J., and Kozarac, Z.: Phytoplankton driven distribution of dissolved and particulate lipids in a semi-enclosed temperate sea (Mediterranean): Spring to summer situation, Estuar. Coast. Shelf S., 93, 290-304, 2011.

Garrett, W. D.: Collection of slick-forming materials from the sea surface, Limnol. Oceanogr., 10, 602-605, 1965.

Gaŝparović, B., Ćosović, B., and Vojvodić, V.: Contribution of organic acids to the pool of surface active substances in model and marine samples using o-nitrophenol as an electrochemical probe, Org. Geochem., 29, 1025-1032, 1998.

Gaŝparović, B., Plavšić, M., Ćosović, B., and Saliot, A.: Organic matter characterization in the sea surface microlayers in the subarctic Norwegian fjords region, Mar. Chem., 105, 1-14, 2007.

Goldman, J. C., Dennett, M. R., and Frew, N. M.: Surfactant effects on air sea gas-exchange under turbulent conditions, DeepSea Res. Pt. A, 35, 1953-1970, 1988.

Guitart, C., Garcia-Flor, N., Bayona, J. M., and Albaiges, J.: Occurrence and fate of polycyclic aromatic hydrocarbons in the coastal surface microlayer, Mar. Pollut. Bull., 54, 186-194, 2007.

Häder, D. P., Helbling, E. W., Williamson, C. E., and Worrest, R. C.: Effects of UV radiation on aquatic ecosystems and interactions with climate change, Photoch. Photobio. Sci., 10, 242-260, 2011.

Hardy, J. T.: The sea surface microlayer: Biology, chemistry and anthropogenic enrichment, Prog. Oceanogr., 11, 307-328, 1982.

Helms, J. R., Stubbins, A., Ritchie, J. D., Minor, E. C., Kieber, D. J., and Mopper, K.: Absorption spectral slopes and slope ratios as indicators of molecular weight, source, and photobleaching of chromophoric dissolved organic matter, Limnol. Oceanogr., 53, 955-969, 2008.

Helms, J. R., Stubbins, A., Perdue, E. M., Green, N. W., Chen, H., and Mopper, K.: Photochemical bleaching of oceanic dissolved organic matter and its effect on absorption spectral slope and fluorescence, Mar. Chem., 155, 81-91, 2013.

Hu, C. M., Muller-Karger, F. E., and Zepp, R. G.: Absorbance, absorption coefficient, and apparent quantum yield: A comment on common ambiguity in the use of these optical concepts, Limnol. Oceanogr., 47, 1261-1267, 2002.

Karanfil, T., Erdogan, I., and Schlautman, M. A.: Selecting filter membranes for measuring DOC and UV254, J. Am. Water Works Ass., 95, 86-100, 2003.

Kattner, G. G. and Brockmann, U. H.: Fatty-acid composition of dissolved and particulate matter in surface-films, Mar. Chem., 6, 233-241, 1978.

Kitidis, V., Stubbins, A. P., Uher, G., Goddard, R. C. U., Law, C. S., and Woodward, E. M. S.: Variability of chromophoric organic matter in surface waters of the Atlantic Ocean, Deep-Sea Res. Pt. II, 53, 1666-1684, 2006.

Knefelkamp, B., Carstens, K., and Wiltshire, K. H.: Comparison of different filter types on chlorophyll $a$ retention and nutrient measurements, J. Exp. Mar. Biol. Ecol., 345, 61-70, 2007.

Kuznetsova, M. and Lee, C.: Dissolved free and combined amino acids in nearshore seawater, sea surface microlayers and foams:
Influence of extracellular hydrolysis, Aquat. Sci., 64, 252-268, 2002.

Lass, K. and Friedrichs, G.: Revealing structural properties of the marine nanolayer from vibrational sum frequency generation spectra, J. Geophys. Res.-Ocean., 116, C08042, doi:10.1029/2010jc006609, 2011

Lass, K., Bange, H. W., and Friedrichs, G.: Seasonal signatures in SFG vibrational spectra of the sea surface nanolayer at Boknis Eck Time Series Station (SW Baltic Sea), Biogeosciences, 10, 5325-5334, doi:10.5194/bg-10-5325-2013, 2013.

Lechtenfeld, O. J., Koch, B. P., Gaŝparović, B., Frka, S., Witt, M., and Kattner, G.: The influence of salinity on the molecular and optical properties of surface microlayers in a karstic estuary, Mar. Chem., 150, 25-38, 2013.

Liss, P. S. and Duce, R. A. (Eds.): The Sea Surface and Global Change, Cambridge University Press, Cambridge, 1997.

McKenna, S. P. and Bock, E. J.: Physicochemical effects of the marine microlayer on air-sea gas transport, in: Marine Surface Films: Chemical Characteristics, Influence on Air-Sea Interactions and Remote Sensing, edited by: Gade, M., Hühnerfuss, H., and Korenowski, G., Springer, Berlin, Heidelberg, 77-91, 2006.

McKenna, S. P. and McGillis, W. R.: The role of free-surface turbulence and surfactants in air-water gas transfer, Int. J. Heat Mass Tran., 47, 539-553, 2004.

Nelson, N. B. and Siegel, D. A.: The Global Distribution and Dynamics of Chromophoric Dissolved Organic Matter, in: Annual Review of Marine Science, edited by: Carlson, C. A. and Giovannoni, S. J., Annu. Rev. Mar. Sci., 5, 447-476, 2013.

Nightingale, P. D., Malin, G., Law, C. S., Watson, A. J., Liss, P. S., Liddicoat, M. I., Boutin, J., and Upstill-Goddard, R. C.: In situ evaluation of air-sea gas exchange parameterizations using novel conservative and volatile tracers, Global Biogeochem. Cy., 14, 373-387, 2000.

Passow, U.: Transparent exopolymer particles (TEP) in aquatic environments, Prog. Oceanogr., 55, 287-333, 2002.

Petrović, M., Fernández-Alba, A. R., Borrull, F., Marce, R. M., Mazo, E. G., and Barceló, D.: Occurrence and distribution of nonionic surfactants, their degradation products, and linear alkylbenzene sulfonates in coastal waters and sediments in Spain, Environ. Toxicol. Chem., 21, 37-46, 2002.

Peuravuori, J. and Pihlaja, K.: Molecular size distribution and spectroscopic properties of aquatic humic substances, Anal. Chim. Acta, 337, 133-149, 1997.

Prowe, A. E. F., Thomas, H., Patsch, J., Kuhn, W., Bozec, Y., Schiettecatte, L. S., Borges, A. V., and de Baar, H. J. W.: Mechanisms controlling the air-sea $\mathrm{CO}_{2}$ flux in the North Sea, Cont. Shelf Res., 29, 1801-1808, 2009.

Salter, M. E.: University of Newcastle upon Tyne, School of Marine Science Technology. A Role for Natural Surfactants in Air-sea Gas Exchange?, PhD Thesis, 45-90, 2010.

Salter, M. E., Upstill-Goddard, R. C., Nightingale, P. D., Archer, S. D., Blomquist, B., Ho, D. T., Huebert, B., Schlosser, P., and Yang, M.: Impact of an artificial surfactant release on air-sea gas fluxes during Deep Ocean Gas Exchange Experiment II, J. Geophys. Res.-Ocean., 116, C11016, doi:10.1029/2011JC007023, 2011.

Schmidt, R. and Schneider B.: The effect of surface films on the air-sea gas exchange in the Baltic Sea, Mar. Chem., 126, 56-62, 2011. 
Schneider-Zapp, K., Salter, M. E., Mann, P. J., and Upstill-Goddard, R. C.: Technical Note: Comparison of storage strategies of sea surface microlayer samples, Biogeosciences, 10, 4927-4936, doi:10.5194/bg-10-4927-2013, 2013.

Schneider-Zapp, K., Salter, M. E., and Upstill-Goddard, R. C.: An automated gas exchange tank for determining gas transfer velocities in natural seawater samples, Ocean Sci., 10, 587-600, doi:10.5194/os-10-587-2014, 2014.

Schulz, K. G., Bellerby, R. G. J., Brussaard, C. P. D., Buedenbender, J., Czerny, J., Engel, A., Fischer, M., Koch-Klavsen, S., Krug, S. A., Lischka, S., Ludwig, A., Meyerhoefer, M., Nondal, G., Silyakova, A., Stuhr, A., and Riebesell, U.: Temporal biomass dynamics of an Arctic plankton bloom in response to increasing levels of atmospheric carbon dioxide, Biogeosciences, 10, 161180, doi:10.5194/bg-10-161-2013, 2013.

Sieburth, J. M. N., Willis, P. J., Johnson, K. M., Burney, C. M., Lavoie, D. M., Hinga, K. R., Caron, D. A., French, F. W., Johnson, P. W., and Davis, P. G.: Dissolved organic-matter and heterotrophic microneuston in surface microlayers of northAtlantic, Science, 194, 1415-1418, 1976.

Stubbins, A., Uhera, G., Kitidis, V., Law, C. S., Upstill-Goddard, R. C., and Woodward, E. M. S.: The open-ocean source of atmospheric carbon monoxide, Deep-Sea Res. Pt. II, 53, 1685-1694, 2006.

Takahashi, T., Sutherland, S. C., Wanninkhof, R., Sweeney, C., Feely, R. A., Chipman, D. W., Hales, B., Friederich, G., Chavez, F., Sabine, C., Watson, A., Bakker, D. C. E., Schuster, U., Metzl, N., Yoshikawa-Inoue, H., Ishii, M., Midorikawa, T., Nojiri, Y., Körtzinger, A., Steinhoff, T., Hoppema, M., Olafsson, J., Arnarson, T. S., Tilbrook, B., Johannessen, T., Olsen, A., Bellerby, R., Wong, C. S., Delille, B., Bates, N. R., and de Baar, H. J. W.: Climatological mean and decadal change in surface ocean $p \mathrm{CO}_{2}$, and net sea-air $\mathrm{CO}_{2}$ flux over the global oceans, Deep-Sea Research Pt. II, 56, 554-577, 2002.

Takahashi, T., Sutherland, S. C., Wanninkhof, R., Sweeney, C., Feely, R. A., Chipman, D. W., Hales, B., Friederich, G., Chavez, F., Sabine, C., Watson, A., Bakker, D. C. E., Schuster, U., Metzl, N., Yoshikawa-Inoue, H., Ishii, M., Midorikawa, T., Nojiri, Y., Körtzinger, A., Steinhoff, T., Hoppema, M., Olafsson, J., Arnarson, T. S., Tilbrook, B., Johannessen, T., Olsen, A., Bellerby, R., Wong, C. S., Delille, B., Bates, N. R., and de Baar, H. J. W.: Climatological mean and decadal change in surface ocean $p \mathrm{CO}_{2}$, and net sea-air $\mathrm{CO}_{2}$ flux over the global oceans, Deep-Sea Res. Pt. II, 56, 554-577, 2009.

Tayler, J. R.: An introduction to error analysis: the study of uncertainties in physical measurements University Science Books, Sausalito, 1996.

Thomas, H., Bozec, Y., Elkalay, K., and de Baar, H. J. W.: Enhanced open ocean storage of $\mathrm{CO}_{2}$ from shelf sea pumping, Science, 304, 1005-1008, 2004.
Thomas, H., Prowe, A. E. F., van Heuven, S., Bozec, Y., de Baar, H. J. W., Schiettecatte, L. S., Suykens, K., Kone, M., Borges, A. V., Lima, I. D., and Doney, S. C.: Rapid decline of the $\mathrm{CO}_{2}$ buffering capacity in the North Sea and implications for the North Atlantic Ocean, Global Biogeochem. Cy., 21, GB4001, doi:10.1029/2006GB002825, 2007.

Tilstone, G. H., Airs, R. L., Martinez-Vicente, V., Widdicombe, C., and Llewellyn, C.: High concentrations of mycosporine-like amino acids and colored dissolved organic matter in the sea surface microlayer off the Iberian Peninsula, Limnol. Oceanogr., 55, 1835-1850, 2010.

Tsunogai, S., Watanabe, S., and Sato, T.: Is there a "continental shelf pump" for the absorption of atmospheric $\mathrm{CO}_{2}$ ?, Tellus $\mathrm{B}, 51$, 701-712, 1999.

Upstill-Goddard, R. C., Frost, T., Henry, G. R., Franklin, M., Murrell, J. C., and Owens, N. J. P.: Bacterioneuston control of air-water methane exchange determined with a laboratory gas exchange tank, Global Biogeochem. Cy., 17, 1108, doi:10.1029/2003gb002043, 2003.

Upstill-Goddard, R. C.: Air-sea gas exchange in the coastal zone, Estuar. Coast. Shelf Sci., 70, 388-404, 2006.

Vodacek, A., Blough, N. V., DeGrandpre, M. D., Peltzer, E. T., and Nelson, R. K.: Seasonal variation of CDOM and DOC in the Middle Atlantic Bight: Terrestrial inputs and photooxidation, Limnol. Oceanogr., 42, 674-686, 1997.

Wanninkhof, R.: Relationship between Wind-Speed and GasExchange over the Ocean, J. Geophys. Res.-Ocean., 97, 73737382, 1992.

Wanninkhof, R. and McGillis, W. R.: A cubic relationship between air-sea $\mathrm{CO}_{2}$ exchange and wind speed, Geophys. Res. Lett., 26, 1889-1892, 1999.

Wanninkhof, R., Hitchcock, G., Wiseman, W. J., Vargo, G., Ortner, P. B., Asher, W., Ho, D. T., Schlosser, P., Dickson, M.-L., Masserini, R., Fanning, K., and Zhang, J.-Z.: Gas exchange, dispersion, and biological productivity on the West Florida Shelf: Results from a Lagrangian Tracer Study, Geophys. Res. Lett., 24, 1767-1770, 1997.

Welschmeyer, N. A.: Fluorometric analysis of chlorophyll a in the presence of chlorophyll-b and pheopigments, Limnol. Oceanogr., 39, 1985-1992, 1994.

Wurl, O. and Holmes, M.: The gelatinous nature of the sea-surface microlayer, Mar. Chem., 110, 89-97, 2008.

Wurl, O., Miller, L., Ruttgers, R., and Vagle, S.: The distribution and fate of surface-active substances in the sea-surface microlayer and water column, Mar. Chem., 115, 1-9, 2009.

Wurl, O., Miller, L., and Vagle, S.: Production and fate of transparent exopolymer particles in the ocean, J. Geophys. Res.-Ocean., 116, C00H13, doi:10.1029/2011jc007342, 2011.

Źutić, V., Ćosović, B., Marĉenko, E., Bihari, N., and Krŝinić, F.: Surfactant Production by Marine-Phytoplankton, Mar. Chem., 10, 505-520, 1981. 